\title{
The Research on Competitive Environment Analysis and Marketing Strategy of Power Sales Company Established By Power Grid Enterprise Based on Electric Power Reform
}

\author{
Ningning ZHAO* \\ North China Electric Power University, No.2, Beinong Road, Huilonguan, \\ Chang-ping District, Bejing, China, 102206 \\ e-mail: znn_2016@163.com \\ *Corresponding author
}

\begin{abstract}
The new reform has brought new challenges and opportunities to the power grid enterprise. The establishment of its power sales company has certain risks and the marketing strategy will be directly related to the survival prospects of the power grid companies and the electricity sales company. Based on the analysis of macro environment and microcosmic environment, combined with enterprise's strategic management and marketing's 4Ps theory analysis, this paper expounds the specific marketing strategy of grid companies to set up sales companies under the background of power reform, and provides reference for the marketing strategy of such kind of sales companies.
\end{abstract}

Keywords-Electric power reform; Electric Power Market; Marketing strategy; Power Sales Company

\section{INTRODUCTION}

In order to break the long-term monopoly situation of China's power industry, enhance the vitality of the electricity market and reduce the electricity consumption of the whole society, on March 15, 2015, the State Council issued "A Number of Opinions on Further Deepening the Reform of the Power System Text ", referred to as the Electric changed to No. 9 text. The article proposed "Steadily push the sales side reform and orderly open to the social capital of the sale of electricity business", which undoubtedly make the sales side reform, become a hot spot in the recent electricity market.

What can be seen through some research on the power enterprises is that some of the current power companies are satisfied with their present situation and doesn't closely follow the step of the power reform, which results in their marketing mechanism is not sound enough and it can't adapt to the new electricity market. The literature [1] provides a brief analysis of the electricity market segmentation and marketing service strategy and puts forward the universal service strategy and the important customer differentiation marketing service strategy as well as the concrete implementation measures. In the literature [2], the fuzzy comprehensive evaluation model is constructed based on the competitiveness of the newly installed electricity mains. The results show that there are quite advantages for the power supply company based on electric power reform. The literature [3] is based on the actual work experience, which analyzes the current situation of power marketing in power grid enterprises under the condition of power market, and gives constructive research results from three aspects: innovative power marketing measures, new electricity consumption market and perfect marketing management system. In the literature [4], the author analyzes the marketing price problems existing in the current power industry from the point of view of marketing price strategy, and analyzes the pricing factors, product cost, market demand and government laws and regulations. He puts forward three aspects of marketing strategy: strengthening the cost control to improve competitiveness, power product discount strategy and strengthening the internal control. Both literature [5] and [6] take a concrete grid enterprise as an example to analyze its competitive environment and internal advantages and disadvantages. Each paper puts forward the strategy which is suitable for the enterprise in the electricity sales market.

Based on the above research results, this paper focuses on the analysis of the competitive environment and marketing strategy of power companies based on power grid enterprises. From the analysis of macro and micro environment, this paper will put forward the corporate strategy and marketing mix in the future electricity market and provide some reference to their deeper development.

\section{MACRO ENVIRONMENT ANALYSIS}

\section{A Political Environment}

The Electric changed to No. 9 text has proposed four important explanations: the importance and urgency of the reform of the power system, the general idea and the basic principle of the reform of the power system, the key tasks of promoting the reform of the power system and the organization and implementation of the reform of the power system. For the establishment of electricity sales company based on power grid companies, the following two options can be selected about the business model provided by the 9th text: run separately or run concurrently. Run separately defined as the company split into two parts: new sales company and the power grid enterprise. The former starts a fair competition with other sellers while the latter is only responsible for the guaranteed service. Run concurrently defined as the grid company retains the sale of electricity business to form an internal sales department, which not only undertakes the sale of electricity business but also is responsible for the guaranteed service. The subsequent text "Opinions on Promoting the sale of electricity side of reform" pointed 
out that the sale of electricity companies should take the customers as the core and achieve self-management, self-risk-taking, self-financing and self-restraint with the operating principles of economic, high quality, safety and environmental protection. The sales company should provide safe, efficient and convenient electricity service for power users from the aspects of providing value-added services such as contract energy management, comprehensive energy saving and electricity consultation.

\section{B Economic Environment}

China will continue to deepen the structural reform of the supply side and optimize the upgrading of industrial structure in 2017. The consumption contribution and the proportion of GDP of service industry will continue to improve. The growth of high-tech and equipment manufacturing industry will be faster than it in general industry. In the meanwhile, unit energy consumption will decline further. The protracted nature and arduousness of China's structural adjustment and kinetic energy conversion have determined the L-type-trend economic growth under the new situation. However, they also have determined that the demand for electricity is difficult to return to high-speed growth channel, and so is to boost the balance of power supply and demand. CEC has expected that 2017 whole social demand of electric power will grow by about $3 \%$. But it is likely to fluctuate about 1 percentage point up and down if there would be extreme weather in summer or winter. In addition, the efforts of steady growth policy measures at all levels of government will likely lead the whole society electricity consumption to fluctuate about 0.5 percentage points.

\section{Social Environment}

As one of a country's economic lifeline, the security and stability of electricity has long been highly valued. However, in the past monopoly system, power grid enterprises are protected by law and have acquired high monopoly profits for a long time, which results in irrational construction investment and unprotected user experience in the absence of competition. Irrational investment in construction has resulted in a waste of government funds and a serious excess of production capacity in some areas; and poor users' experience has reduced the reputation of the public. The voices of demand for electricity market to open and the independent choice of users are getting higher and higher. Moreover, the environmental awareness gradually rooted in the public mind with the increase in pollution, and the pursuit of green living is becoming a new philosophy of life. According to the survey, consumers pay more attention to energy consumption, radiation and other environmental conditions than ever before and they are willing to pay for more than 2 to 3 times the price of environmentally friendly products, which means that energy-saving services will become a new hot spot of power services. In addition to environmental protection, people are more eager for convenient and efficient service under the background of Internet information age, and humane and personal service is becoming a new selling point with the gradual growth of individual-pursuit generation.

\section{Technical Environment}

With the rise of big data analysis technology and the aid of existing customer information management system, business offices, 95598 hot-line, micro-channel public platform, corporate website, hand-held power APP and other diverse media tools, the sales company established by power grid enterprises can collect customer electricity information and analyze the habit of customer energy usage, which will lay a solid foundation for future power precision marketing. In the future, the gradual advancement of the global energy Internet will also promote the sale of electricity companies to provide more high-quality power and energy services.

\section{MicROCOSMIC ANALYSIS}

\section{A Strength}

The sales company established by power grid enterprises can take advantages of ample reserve power grid enterprises marketing personnel, perfect business hall network facilities, popular 95598 telephone and website services, long-term electricity sales experience, high brand awareness and reputation, reliable power supply quality, rich user information and other high-quality resources as well as learn from the power grid enterprise system construction and service system to quickly developed a set of service mechanism that can both meet the needs of users and bring benefits for the enterprise under the premise of adapting to market-oriented operating mechanism.

\section{B Weakness}

The weakness of the sales company, which is established by power grid enterprise, shows in the following aspects. First, they lack of marketing concept and determination. Second, the universal service costs are getting higher annually. Third, there is no fixed source of energy for them to deploy timely. Forth, their energy management business is sole when it is compared with energy - saving service's company. Fifth, the management gets difficult and the communication is not smooth for the number of power supply companies at all levels being huge and the existence of regional barriers, which bring some obstacles to its development. Additionally, compared with other types of power sales companies, its system cumbersome, lacking of motivation and the inherent concept of business result in it not bold enough to innovate in the early development of the market. Furthermore, the solidified personnel system and the gradually falling staff welfare will "get rid of" a number of excellent electricity talent.

\section{Opportunity}

The new electricity reform related document stipulates that: doesn't limit the sales capacity of companies that the total assets is more than RMB 200 million; one power supply business area can have a number of electricity sales company, but only one company has the right to operate the distribution network, 
and provide support services. It means that the sales company based on power grid companies has a greater chance to operate distribution network, and the strong capital can also support its development of the market, increase competition with the distribution network opportunities. The new electricity reform introducing competition mechanism also can promote the power grid company cost control and improve its investment flexibility, which will bring new development direction and business philosophy.

\section{Threats}

Since the start of the new electricity reform, there are at least 559 sales of electricity companies have been set up in the whole country. The joint of new market players means that profits will be re-divided. To encourage large users to purchase electricity will make power grid companies lost a considerable number of industrial users in the absence of the price advantage . The competition of the marketing talent between the companies will also make it lose some excellent staff. The energy-saving program of Energy-saving service's company will attract a lot of high-power enterprises. Distributed power and other low-cost electricity will also impact the demand of customers for power grid enterprise. And the new policy which acquires grid companies to bear the responsibility of security services will also increase the operating costs .The growth of bargaining ability of power plants and customers will further compress profit margins of the sales companies.

\section{ENTERPRISE STRATEGY ANALYSIS}

\section{A Market Segmentation}

According to the degree of price sensitivity, power quality sensitivity, the quality of service sensitivity and the electricity consumption, the user groups can be roughly divided into the following categories which are shown in the Table 1.

TABLE I. MARKET SEGMENTATION

\begin{tabular}{|c|c|c|c|}
\hline $\begin{array}{l}\text { Customer } \\
\text { classification }\end{array}$ & $\begin{array}{l}\text { Typical } \\
\text { representative }\end{array}$ & Features & Appeal \\
\hline $\begin{array}{l}\text { High price } \\
\text { sensitivity users }\end{array}$ & $\begin{array}{l}\text { Large industrial } \\
\text { users }\end{array}$ & $\begin{array}{l}\text { They are extremely sensitive to the price; the } \\
\text { requirements of power quality are higher; the } \\
\text { requirements of service quality are general; } \\
\text { The electricity consumption is huge. }\end{array}$ & $\begin{array}{l}\text { Price is their primary consideration. Any } \\
\text { price changes will cause them to make a } \\
\text { new choice }\end{array}$ \\
\hline $\begin{array}{l}\text { High service quality } \\
\text { sensitivity users }\end{array}$ & $\begin{array}{l}\text { Domestic user; } \\
\text { General industrial } \\
\text { and } \quad \text { commercial } \\
\text { users }\end{array}$ & $\begin{array}{l}\text { They both enjoy the cross subsidy. They are } \\
\text { extremely sensitive to the service quality; the } \\
\text { sensitivity of price is general; the } \\
\text { requirements of power quality are higher; } \\
\text { The electricity consumption is much. }\end{array}$ & $\begin{array}{l}\text { The knowledge and skills of electricity } \\
\text { usage of this type of customer are not } \\
\text { professional. They pursuit convenient } \\
\text { and efficient electricity service, and the } \\
\text { quality of service often determines } \\
\text { whether they are willing to continue to } \\
\text { cooperate with the current sales } \\
\text { company. }\end{array}$ \\
\hline $\begin{array}{l}\text { High power quality } \\
\text { sensitivity users }\end{array}$ & $\begin{array}{l}\text { Advanced scientific } \\
\text { research users; } \\
\text { Government } \\
\text { enterprises and } \\
\text { institutions users }\end{array}$ & $\begin{array}{l}\text { They are extremely sensitive to the power } \\
\text { quality and service quality; while they are not } \\
\text { sensitive to the price; The electricity } \\
\text { consumption is large. }\end{array}$ & $\begin{array}{l}\text { Most of these users belong to the first } \\
\text { power supply level. Because the power } \\
\text { quality instability often can cause } \\
\text { immeasurable losses, so the company } \\
\text { with a reliable power quality is their first } \\
\text { choice. }\end{array}$ \\
\hline $\begin{array}{l}\text { Small power } \\
\text { consumption users }\end{array}$ & $\begin{array}{l}\text { Agricultural } \\
\text { irrigation and rural } \\
\text { electricity users }\end{array}$ & $\begin{array}{l}\text { They only sensitive to the price; the } \\
\text { requirements of power quality and service } \\
\text { quality are general; the electricity } \\
\text { consumption is small. }\end{array}$ & $\begin{array}{l}\text { The load characteristics of such users } \\
\text { have a clear timeliness and seasonal, the } \\
\text { electricity sales companies can make a } \\
\text { comprehensive service program based on } \\
\text { the above situation. }\end{array}$ \\
\hline
\end{tabular}

\section{B Target Market}

How to use existing resources for market share and operating profit, the choice of target market will play a decisive role for the sales company based on power grid enterprise. Under the situation of gradual loss of price advantage and bargaining ability, universal service costs increasing year by year and profit margins being compressed step by step, they should actively change their thinking, carefully study the government policy, do a good job in load forecasting and price bidding both at the same time do a good job of electricity service work to protect the rural and public welfare business, obtain profits from the residents of users, advanced scientific research users, government enterprises and institutions users and create a good corporate image and service reputation at the same time, and strive for a complete power supply facilities, more preferential prices and value of the additional services to attract large industrial users.

\section{Market Positioning}

The sales company established by power grid enterprise should continue to adhering to the service concept of "You use electricity, I use heart", combined with the current "Internet plus", "cloud computing, big data, Internet of material, Mobile Internet, Smart City" and other scientific and technological background, become a model of green, efficient, intelligent power service provider and a good user's "electric babysitter". Its services should take the users as the core and take the economy, quality, safety, environmental protection as the operating principle to bear the social responsibility of affordable electricity and actively explore and provide 
electricity auxiliary services, contract energy management, comprehensive energy, electricity consulting, electricity rescue, regulating electricity load and other value-added services at the same time.

\section{MARKETING MiX STRATEGY}

\section{A Product Strategy}

Power products not only include the power itself but also include other services around the power, which mainly including energy metering and payment, industry expansion equipment, power maintenance, other consulting services. In addition, with the diversification of user demand for electricity services, the new power products can be dug as such types which are shown in the Table 2.

\section{B $\quad$ Price Strategy}

\section{1) Power Purchasing Strategy}

Combined with the trading policy in current power trading center and based on various basic data of current production and business activities, build economic analysis and evaluation indicators. (Analysis of Profit Indicators, Cost analysis, Price analysis, Capital analysis, The amount of profit analysis, Sensitivity analysis, Comprehensive economic analysis). Through all-round, multi-angle comprehensive analysis, comparison and prediction of the different accounting, match the transaction offer to provide a comprehensive and accurate decision-making basis.

\section{2) Power Selling Strategy}

Establish users' credit evaluation system and carry out forward sale system to lower credit level of users. Sign long term power supply agreement to higher credit level of users who can be implemented on credit marketing system, meaning using after payment. In addition, According to the user's different requirements of the service level, it can be charged different grades of service costs, and make the appropriate service commitments. Assess the value of customers by using customer information management system, and reward high value customers with incentives to promote long-term cooperation; Practice the points system for low-value customers, which can be used to exchange electricity or electricity services, increasing customer stickiness.

\section{3) Channel Strategy}

On the basis of overall planning and rational layout, promote a comprehensive coverage of urban and rural power business outlets to provide customers with a comfortable and beautiful power operating environment. At the same time, power companies and banks strengthen cooperation with mobile network, which effectively improves the efficiency of electricity services and convenience.

\begin{tabular}{|c|c|}
\hline $\begin{array}{l}\text { Energy } \\
\text { self-supply }\end{array}$ & $\begin{array}{l}\text { On the basis of the promotion of distributed power supply and distributed energy storage, various types } \\
\text { of users can meet their own demand for energy. If there is a surplus, the distributed energy nodes can be } \\
\text { arranged in place. For example, equipped the wind and solar power supply system in the commercial } \\
\text { center, while install the electric vehicle charging pile powering by this system in the vicinity. }\end{array}$ \\
\hline $\begin{array}{l}\text { Energy } \\
\text { agency }\end{array}$ & $\begin{array}{l}\text { The intermediaries collect all kinds of users 'energy needs with acceptance and offer uniformly. Brokers } \\
\text { establish foundry relations with a number of energy providers . The latter produce the corresponding } \\
\text { energy and provide to users. }\end{array}$ \\
\hline $\begin{array}{l}\text { Energy } \\
\text { group buy }\end{array}$ & $\begin{array}{l}\text { Similar to the network group buy existing. Users gather purchasing power to promote the users' status in } \\
\text { the market game; at the same time the energy providers get a platform for mass sales, benefiting to its } \\
\text { unified control. Applicable to decentralized but total amount of urban and rural individual user groups, is } \\
\text { conducive to saving bilateral costs. }\end{array}$ \\
\hline $\begin{array}{l}\text { Energy } \\
\text { rescue }\end{array}$ & $\begin{array}{l}\text { Response to the sudden energy interruption. The user contacts the energy rescue company, and the } \\
\text { company assigns the local energy rescue service stations to provide users with emergency energy supply. } \\
\text { The energy rescue company collects fees and commissions for energy use on a case-by-case basis. }\end{array}$ \\
\hline $\begin{array}{l}\text { Energy } \\
\text { futures }\end{array}$ & $\begin{array}{l}\text { Determine the energy trading futures specifications in the standard form .emerging energy suppliers can } \\
\text { attract users by lower futures prices in order to achieve financing. Stocks have been commonplace. In the } \\
\text { future, with the new electric reform in depth, "Fried electricity" can also look forward to. }\end{array}$ \\
\hline $\begin{array}{l}\text { Energy } \\
\text { guarantee }\end{array}$ & $\begin{array}{l}\text { When large and medium-sized users trade with energy providers, brokers guarantee both supply and } \\
\text { demand to improve transaction efficiency and speed up the flow of funds. }\end{array}$ \\
\hline $\begin{array}{l}\text { Energy } \\
\text { bottled }\end{array}$ & $\begin{array}{l}\text { Standardization of energy services, including standardized energy storage equipment, standardized } \\
\text { energy supply curve and energy format contract. This model is suitable for small and medium-sized } \\
\text { urban and rural users, allowing users to diversify the self-energy consumption structure more easily. }\end{array}$ \\
\hline $\begin{array}{l}\text { "Didi" } \\
\text { Energy }\end{array}$ & $\begin{array}{l}\text { Provide personalized point-to-point energy services for different types of energy users. Users can publish } \\
\text { their own demand information to the system platform, and the nearby energy suppliers can match or } \\
\text { ignore users after browsing the released information. Once the match is confirmed, the two parties may } \\
\text { conduct further consultations and transactions. This model is suitable for all types of users. With the } \\
\text { development of energy Internet technology, the types of user needs will continue to expand. }\end{array}$ \\
\hline $\begin{array}{l}\text { Energy } \\
\text { "WiFi" }\end{array}$ & $\begin{array}{l}\text { With the wireless charging and other technologies further developing and popularizing, providing users } \\
\text { with a wide range of wireless charging services is possible. The users connect the wireless charging hot } \\
\text { spot, which charges the equipment with the energy, and then use the bound account to pay the charge. } \\
\text { Wireless hot spots mainly cover commercial and residential users. }\end{array}$ \\
\hline $\begin{array}{l}\text { Energy } \\
4.0\end{array}$ & $\begin{array}{l}\text { Based on the highly automated production, arrange energy products and services program for users. The } \\
\text { scope of this model will be gradually extended with the technological innovation, and to cover all types } \\
\text { of user units ultimately. }\end{array}$ \\
\hline
\end{tabular}




\section{Promotion Strategy}

\section{1) Personnel Promotion Strategy}

Strengthen the business training of electric power marketing staff to break the traditional "waiting customers" ideas and serve the customer to the door forwardly. In the process of customer service, electricity companies should promote the needs of customers actively, achieving a win-win and long-term cooperation with customers.

\section{2) Advertising Strategy}

With the gradual increase in the main sales of electricity, the user's choice has become more. How to stand out in many the main sales body and seize the user's line of sight, not only rely on high-quality electricity and good service, but also strengthen the concept of publicity, establish a reputation image. Sales companies founded by grid enterprise can combine their own market positioning and users' information channels for corporate philosophy and product promotion to attract users and maintain market share.

\section{3) PR Strategy}

Provide the power supply protection work actively for the local economic construction program and communicate with the local government effectively. Provide electricity protection and actively solve their electricity problems for the local large-scale projects. Organize social service teams and troubleshoot power hidden dangers regularly for the area of electricity users. Enhance corporate social image and public reputation to achieve social and economic benefits of a win-win goal.

\section{CONCLUSIONS}

Power Grid Company has great advantages in the electricity market competition, but it should not ignore the short boards which can be improved. They must pay attention to the reform dynamics regularly, combine own situations and users' needs, identify the target of market, accurate business positioning, carry out the depth of mining in products and services, develop a scientific and rational pricing mechanism, build excellent corporate images and publicity, and learn from the views of customers actively and feedback timely. Only does a good job in every step above can make enterprises grow and develop.

\section{REFERENCES}

[1] Peng LI. 2016. Practical Electronic. (In Chinese)

[2] Kang-ren HUANG. Research on Competitive Strategy of Power Sales Company Based on Electric Power System Reform. D. Beijing: North China Electric Power University. 2016. (In Chinese)

[3] Ya-dong LI.2016.Technology Innovation and Application. (In Chinese)

[4] Chun-fang LI.2016.Shandong Industrial Technology. (In Chinese)

[5] Fang WANG. Research on Electricity Marketing Strategy: a special case of H Power Supply Company. D. Hei Longjiang: Heilongjiang University. 2016. (In Chinese)

[6] Quan ZHOU. Research on Electricity Marketing Strategy: a special case of Nanjing Power Supply Company. D. Beijing: North China Electric Power University. 2016. (In Chinese) 